\title{
Influencing Factors Nurse Behavior in Providing Service in Installation Distric General Hospital Praya Central Lombok
}

\author{
Teguh Achmalona, Sentot Imam, \\ Indasah \\ General Hospital Praya Central \\ Lombok, Indonesia \\ Email: \\ teguhachmalona@gmail.com
}

Received : March 12, 2019

Accepted : October 13, 2019

Published : November 26, 2019
ABSTRACT

Nursing services are an integral part of health services in hospitals, which have a very strategic position in efforts to improve the quality of care in hospitals, thus demanding the professionalism of nurses in providing and regulating nursing care activities to patients. The purpose of this study was to determine the effect of leadership, competency, motivation, workload and reward factors on the behavior of nurses in providing services in installation distric general hospital Praya.The research design used was quantitative analytic with a cross sectional approach. The sampling technique uses cluster random sampling with a sample of 114 respondents. Data was collected using questionnaires and observation sheets, then analyzed using ordinal regression test. The results showed, from the results of a statistical test simultaneously obtained $p$ value of $0.000<\alpha=0.05$, meaning that all independent variables together affect the dependent variable. The results of statistical tests partially obtained the results there is an influence between leadership, competence, motivation, workload and reward with nurse behavior, with $\mathrm{p}$ values for each variable, namely leadership ( $\mathrm{p}<0.012)$, competence $(\mathrm{p}<0.008)$, motivation ( $\mathrm{p}<0.006$ ), workload $(\mathrm{p}<0.012)$, and reward ( $\mathrm{p}$ $<0.000$ ). Multivariate analysis shows that reward is the most dominant variable affecting the behavior of nurses in providing nursing services with a value $(p<0,000)$. Nurse behavior is influenced by factors of leadership, competence, motivation, workload and rewards, so that these aspects need to be managed well in the hope of getting better results of nurse performance and behavior.

Keywords: Leadership, Competence, Motivation, Workload, Reward and Nurse Behavior

\section{(c) (1) ()}

This is an open-acces article distributed under the terms of the Creative Commons Attribution-ShareAlike 4.0 International License. 


\section{INTRODUCTION}

The hospital is one of the means of health efforts that provide health services to the community has a strategic role in accelerating the improvement of public health degrees as a goal of health development. Therefore, hospitals are always required to provide quality services in accordance with established standards (Kepmenkes, 2012).

Nursing services are an integral part of health services in hospitals, which have a very strategic position in efforts to improve the quality of existing services. Nursing services are often used as a benchmark for the image of a hospital in the eyes of the community, thus demanding the professionalism of the nursing nurse and the nurse manager in providing and regulating nursing care activities to patients. In carrying out or carrying out their duties, nurse is required to always develop attitudes, behavior and knowledge in providing nursing care. These attitudes and behaviors are shown by giving positive encouragement, providing a sense of comfort, support, attention, affection, caring, empathy, love, trust, protection, and being ready to help when needed. This behavior will encourage patients to change physical, psychological, spiritual and social aspects towards a better direction (Herwyndianata, 2013).

According to Gibson, individual nurses are influenced by 3 variables, namely individual variables, organizational variables and psychological variables. Individual variables consist of abilities, skills, knowledge, demographics and family background. Psychological variables consist of perception, attitude, motivation, personality and learning. Organizational variables consist of resources, rewards, workload, structure, supervision and leadership (Hasmoko, 2012). .

Praya Regional General Hospital (RSUD) is a type C hospital in Central Lombok Regency with a capacity of 279 beds with a total of 276 nursing staff from December 2017. With details of 109 people in the status of civil servants (PNS) and 167 people in the status of non-permanent employees (PTT). Existing data shows a decrease in the number of BOR from $75.3 \%$ in 2016 decreased to $69.9 \%$ in 2017. The level of patient satisfaction with nursing services is only $65 \%$, the figure is still below the quality standards set by hospital management namely by $80 \%$. The complaint is mostly related to the behavior of nurses in providing nursing services that are still felt to be very lacking which causes patient dissatisfaction with the quality of service. If this is allowed to continue continuously, it can reduce the interest of patients to choose hospitalization in the hospital, can cause a decrease in the relationship of mutual trust, increasing psychological burden that affects the healing process of patients, causing a sense of insecurity and comfort towards the patient (Profil RSUD Praya).

The behavior displayed by the nurse in providing nursing services is a response and action to the needs and desires of the patient. If it is left unchecked it will have a negative impact on the image and performance of a hospital. This study aims to analyze the factors that influence the behavior of nurses in providing services in installation distric general hospital Praya.

\section{MATERIALS AND METHODS}

This study uses quantitative analytical methods using a cross sectional approach. The population in this study amounted to 160 nurses in charge and involved in the provision of nursing care in the inpatient installation of Praya hospital. The sample size in the study was 114 respondents using cluster random sampling technique. The independent variables in this study are leadership, competence, nurse motivation, workload and reward. While the dependent variable in this study is the behavior of nurses. Data was collected using questionnaires and observation sheets, then analyzed using ordinal regression test.

\section{RESULT}

\section{Distribution of respondent characteristics}

Table 1. Distribution of characteristics of respondents based on age, gender, education, and years of service in Praya hospital

\begin{tabular}{|c|c|c|c|}
\hline No. & Characteristics & Frekuensi & Persentase (\%) \\
\hline \multirow[t]{4}{*}{1} & Age (year) & & \\
\hline & $<25$ & 15 & 13,2 \\
\hline & $26-30$ & 61 & 53,5 \\
\hline & $31-35$ & 38 & 33,3 \\
\hline
\end{tabular}




\begin{tabular}{|c|c|c|c|}
\hline 2 & Gender & & \\
\hline & Male & 69 & 60,5 \\
\hline & Female & 45 & 39,5 \\
\hline \multirow[t]{4}{*}{3} & Education & & \\
\hline & Ners & 50 & 43,9 \\
\hline & SI & 35 & 30,7 \\
\hline & DII & 29 & 25,4 \\
\hline \multirow[t]{3}{*}{4} & Years of service & & \\
\hline & $<10$ & 82 & 71,9 \\
\hline & $>10$ & 32 & 28,1 \\
\hline
\end{tabular}

Based on the above table of 114 respondents there were 61 respondents (53.5\%) in the 26-30 years age group, 69 respondents $(60.5 \%)$ of whom were male. 50 respondents $(43.9 \%)$ have ners education. 82 respondents $(71.9 \%)$ had a service life of less than 10 years.

Distribution of variable characteristic

Table 2. Distribution of variable characteristics based on leadership, competence, motivation, reward and behavior in Praya hospital.

\begin{tabular}{|c|c|c|c|}
\hline No & Characteristics & Frekuensi & Persentase (\%) \\
\hline \multirow[t]{4}{*}{1} & Leadership & & \\
\hline & Less & 12 & 10,5 \\
\hline & Enough & 66 & 57,9 \\
\hline & Good & 36 & 31,6 \\
\hline \multirow[t]{4}{*}{2} & Competence & & \\
\hline & Less & 12 & 10.5 \\
\hline & Enough & $\begin{array}{l}12 \\
83\end{array}$ & $\begin{array}{l}10,3 \\
728\end{array}$ \\
\hline & Good & $\begin{array}{l}83 \\
19\end{array}$ & $\begin{array}{l}12,8 \\
16,7\end{array}$ \\
\hline \multirow[t]{4}{*}{3} & Motivation & & \\
\hline & Less & 3 & 2,6 \\
\hline & Enough & 85 & 74,6 \\
\hline & Good & 26 & 22,8 \\
\hline \multirow[t]{4}{*}{4} & Work load & & \\
\hline & Low & 4 & 3,5 \\
\hline & Medium & 81 & 71,1 \\
\hline & High & 29 & 25,4 \\
\hline \multirow[t]{4}{*}{5} & Reward & & \\
\hline & Low & 11 & 9,6 \\
\hline & Medium & 65 & 57,0 \\
\hline & High & 38 & 33,3 \\
\hline \multirow[t]{4}{*}{6} & Behavior & & \\
\hline & Less & 23 & 20,2 \\
\hline & Enough & 59 & 51,8 \\
\hline & Good & 32 & 28,1 \\
\hline
\end{tabular}

Based on the above table of 114 respondents there were 59 respondents $(51.8 \%)$, sufficient leadership, 81 respondents $(71.1 \%)$ sufficient nurse competence, 85 respondents $(74.6 \%)$ had enough motivation, 81 respondents $(71.1 \%)$ workload of nurses are being, 65 respondents $(57.0 \%)$ reward medium nurses, and 59 respondents $(51.8 \%)$ had sufficient nurse behavior. 
The results of statistical tests simultaneously obtained $p$ value of $0.000<\alpha=0.05$, meaning that all independent variables together affect the dependent variable. The results of statistical tests partially with a significant level of $\alpha=0.05$ obtained results there is an influence between leadership, competence, motivation, workload and reward with nurse behavior. The $\mathrm{p}$ value for each variable is leadership ( $\mathrm{p}<0.012$ ), competence ( $\mathrm{p}<0.008$ ), motivation ( $\mathrm{p}<0.006$ ), workload ( $\mathrm{p}<0.012$ ), and reward ( $\mathrm{p}<0.000)$. Multivariate analysis shows that reward is the most dominant variable that influences the behavior of nurses in providing services in installation distric general hospital Praya with a value $(\mathrm{p}$ $<0,000)$

\section{DISCUSSION}

\section{The influence of leadership on the behavior of nurses in providing services in installation distric general hospital Praya.}

Based on the results of ordinal regression analysis, the leadership variable has a $p$-value $=0.012$ $<\alpha=0.05$ so $\mathrm{H} 0$ is rejected and $\mathrm{H} 1$ is accepted. Based on the p-value, it can be explained that there is an influence of leadership on the behavior of nurses in providing services in installation distric general hospital Praya.

Leadership is the art of encouraging or influencing others to do or what a leader wants to do or ways for a leader to influence the behavior of his subordinates, to be willing to work together and work productively to achieve organizational goals. Every employee behavior in an organization is often influenced by the behavior of the leader. The style or attitude shown by the leader will color the way of thinking of the employees, which in turn will influence the behavior and discipline and work performance of employees in an organization. So the leader must be a good role model for his subordinates (Sutikno, 2014).

\section{The influence of competence on the behavior of nurses in providing services in installation distric general hospital Praya.}

Based on the results of ordinal regression analysis competency variables have $p$-value $=0.008$ $<\alpha=0.05$ so $\mathrm{H} 0$ is rejected and $\mathrm{H} 1$ is accepted. Based on the p-value, it can be explained that there is an influence of competence on the behavior of nurses in providing services in installation distric general hospital Praya.

Competence is the ability to carry out work or tasks based on skills and knowledge and is supported by work attitudes set by the work. The competencies possessed by a nurse include intellectual, physical and human relationships which are the basis for nurses in carrying out nursing care. That is, if a nurse has good competence then in carrying out his duties will have a good impact on patients and families, and vice versa if a nurse has less competence then in carrying out their duties will have an adverse impact on patients (Kurniadi, 2013).

So that in carrying out and carrying out nursing service activities, a nurse is required to use the existing knowledge and theory in nursing science and can be accounted for in order to achieve maximum service goals. That is why the competence of a nurse in providing nursing services is something that must be owned and controlled by a nurse in the process of providing nursing care (Budiawan, 2016).

\section{The influence of motivation on the behavior of nurses in providing services in installation distric general hospital Praya.}

Based on the results of ordinal regression analysis variable motivation has a $\mathrm{p}$-value $=0.006$ $<\alpha=0.05$ so that $\mathrm{H} 0$ is rejected and $\mathrm{H} 1$ is accepted. Based on the p-value, it can be explained that there is an influence of motivation on the behavior of nurses in providing services in installation distric general hospital Praya.

Motivation is the power, both inside and outside that encourages someone to achieve certain goals that have been set beforehand. The need for achievement is the driving force that motivates nurses to behave and work with enthusiasm, because the need for achievement will encourage nurses to develop creativity and move all their abilities to achieve maximum performance, as well as the application of behavior. Nurses who have high achievement motivation will work and behave better than before to achieve better performance (Hamzah, 2011). 
The motivation of nurses in providing nursing services related to the desire to carry out their responsibilities as a nursing service provider to serve patients well during the treatment process. This awareness is what makes a person's motivation can affect behavior, because behavior based on knowledge and awareness will be better than behavior that is not based on knowledge and awareness, before a person adopts a behavior he must know in advance what the meaning and benefits of the behavior for him or organization (Ridwan, 2013).

\section{The influence of workload on the behavior of nurses in providing services in installation distric general hospital Praya.}

Based on the results of ordinal regression analysis the variable workload has a $p$-value $=0.012$ $<\alpha=0.05$ so that $\mathrm{H} 0$ is rejected and $\mathrm{H} 1$ is accepted. Based on the p-value, it can be explained that there is an effect of workload on the behavior of nurses in providing services in installation distric general hospital Praya.

Workload is the ability of the body of the worker to receive work. Every workload received by a person must be appropriate and balanced with the physical and psychological abilities of the worker who receives the workload. According to Kurniadi A. (2013), which affects the workload of nurses is the condition of patients who are always changing, the average number of hours of care needed to provide direct services to patients and nursing care documentation, as well as many additional tasks that must be done by a person nurse so that it can affect the performance of the nurse.

If someone is in a work environment with a high workload, most likely the person does not produce satisfactory performance and can even cause saturation. For this reason, efforts must be made to harmonize work capacity, workload and work environment in order to obtain optimal work productivity which will ultimately have a positive impact on the quality of service available (Sudirman, 2013).

\section{The influencing of reward on the behavior of nurses in providing services in installation distric general hospital Praya}

Based on the results of ordinal regression analysis the reward variable has a $p$-value $=0,000<\alpha$ $=0.05$ so $\mathrm{H} 0$ is rejected and $\mathrm{H} 1$ is accepted. Based on the p-value, it can be explained that there is an effect of reward on the behavior of nurses in providing services in installation of Praya Hospital.

Reward is a form of recognition to a certain achievement given in material and non-material forms provided by the organization or institution to individuals or groups of employees so that they can work with high motivation and achievement in achieving organizational goals. The awards given are in the form of material or non-material that aims to attract, maintain and motivate employees to achieve high work performance (Handoko, 2012).

Awarding will encourage nurses to work productively. Nurses can work optimally if they are satisfied with what they do or clearly the work that must be completed and what benefits they receive are in accordance with their performance and competencies. Provision of good rewards as a form of reward for services that have been done makes nurses feel valued and recognized. Reward has an important role in an organization because it is a reflection of part of the way to maintain human resources that are able to work in accordance with organizational goals. If the organization does not pay good attention to compensation for its employees, it is not impossible that the organization will gradually lose high-quality human resources that can even cause a decline in the performance of both workers and organizations (Jusuf, 2013).

The dominant factor that most influences the behavior of nurses in providing services in installation distric general hospital Praya.

Based on the results of ordinal regression analysis the reward variable has a $p$-value $=0,000<\alpha=0.05$ so $\mathrm{H} 0$ is rejected and $\mathrm{H} 1$ is accepted. Based on the p-value, the reward variable is the variable that has the most influence on the behavior of nurses in providing services in the inpatient installation of Praya Hospital.

Giving awards will be able to encourage nurses to work productively. Nurses can work optimally if they are satisfied with what they do or clearly the work that must be completed and what rewards they receive are in accordance with the performance and competencies they have, therefore the nurse behaves well because she feels valued and recognized. Nurses want to be recognized / valued 
according to the competencies they have. The high or low reward received by a nurse will influence the quality of services provided ( Handoko, 2012).

If management wants employees to provide good services, employees must be given appropriate rewards. Giving rewards are not always in the form of money because the form of material but can also be in the form of non-material in the form of a conducive work atmosphere, opportunities for creativity development, less stringent work conditions and more humane working conditions (Royani, 2010).

\section{CONCLUSION}

Based on the results of the study it can be concluded that there is an influence between leadership, competence, motivation, workload and reward with nurse behavior. reward is the most dominant variable that influences the behavior of nurses in providing nursing services.

\section{REFERENCES}

Budiawan. (2016). Hubungan Kompetensi. Motivasi Dan Beban Kerja Dengan Kinerja Perawat Pelaksana Di Ruang Rawat Inap Rumah Sakit Jiwa Provinsi Bali.

Uno, H., B. (2011). Teori motivasi dan pengukurannya: analisis di bidang pendidikan. Jakarta: Bumi Aksara.

Handoko, H. (2012). Manajemen personalia dan sumber daya manusia. BFFE, Yogyakarta.

Hasmoko, E., V. (2012). Analisis Faktor-Faktor Yang Mempengaruhi Kinerja Klinis Perawat Berdasarkan Penerapan Sistem Pengembangan Manajemen Kinerja Klinis Di Ruang Rawat Inap Rumah Sakit Panti Wilasa Citarum Semarang [Tesis]. Semarang: Universitas Diponegoro.

Herwyndianata, Balqis, \& Darmawansyah. (2013). Analisis Faktor Yang Berhubungan Dengan Kinerja Perawat Dalam Penerapan Standar Asuhan Keperawatan Di Unit Rawat Inap RSU Anuta pura Palu tahun 2013. Makassar: Universitas Hasanudin.

Kepmenkes No.129 tahun (2008). Tentang Standar Pelayanan Minimal RS.

Kurniadi, \& Anwar. (2013). Manajemen Keperawatan dan Prospektifnya: Teori dan Aplikasi. Jakarta. Fakultas Kedokteran Universitas Indonesia.

Martono, \& Nanang. (2012). Metode Penelitian Kuantitatif: Analisis Isi dan Analisis Data skunder, Ed. Revisi. Jakarta: Rajawali Pers.

Profil Rumah Sakit Umum Daerah Praya tahun 2017.

Ridwan L., F. (2013). Pengaruh Motivasi Intrinsik dan Motivasi Ekstrinsik Terhadap Kinerja Perawat Suatu Kajian Literatur. Bandung: Universitas Padjajaran.

Royani. (2010). Hubungan Sistem Penghargaan dengan Kinerja Perawat dalam Melaksanakan Asuhan Keperawatan di Rumah Sakit Umum Daerah Cilegon Banten [Tesis]. Jakarta: UI.

Sudirman. (2013). "Hubungan Beban Kerja dengan Kinerja Perawat Pelaksana di Ruang Rawat Inap Instalasi Penyakit Dalam RSMH Palembang" (Tesis). Palembang.

Sutikno, \& Sobry, M. (2014). Pemimpin dan gaya kepemimpinan, edisi pertama Lombok: Holistica 